\title{
The Comparison of Aggression between Professional and Semi-Professional Male Taekwondo Athletes in Isfahan, Iran
}

\author{
Mojtaba Salemi khozani \\ Faculty of Humanities, \\ Islamic Azad University, Science and Research Branch \\ Tehran, Iran \\ mortezasalemi@yahoo.com (Correspondence author) \\ Kaveh Khabiri \\ Faculty of Humanities, \\ Islamic Azad University of Ashtian, Arak, Iran \\ sepka_kh@yahoo.com \\ Bahram Ghadimi \\ Faculty of Humanities \\ Islamic Azad University, Science and Research Branch, Tehran, Iran \\ B.ghadimi@gmail.com \\ Sepideh Mehraein \\ Faculty of Educational Studies \\ Universiti Putra Malaysia (UPM), Malaysia \\ sepideh20_k@yahoo.com \\ Aida Mehrad \\ Faculty of Psychology \\ Universitat Autònoma de Barcelona (UAB), Spain \\ aida_238@yahoo.com
}

\begin{abstract}
Aggression is one of the general phenomenon that athletes often directly or indirectly deal with. There are rare issues that are significant as much aggression and violence in sport. The explanation for violent behavior in humans is often the subject of research in the science of sociology. Social changes around the world in recent centuries had a significant impact on cultural structure. In this study, the researchers focused on the aggression of professional and semi-professional athletes in Taekwondo in Isfahan, Iran. The cross-sectional method was applied in this study. To analyze, we examined the relationships between predictor variables and the dependent variable or the variance criterion to explain the changes. The results shown that there was no significant difference between terms of anger and physical aggression among professional and semi-professional. On the other hand, there was meaningful differences between verbal aggression and hostility amongst participants. In addition, the amounts of aggression amongst professional players were more than semi-professional players.
\end{abstract}

Keywords: Aggressive, Athlete, Iran, Isfahan, Professional, Semi-professional, Taekwondo 


\section{Introduction}

The aggression assumed as one of the general difficulties that athletes often directly or indirectly deal with. There are rare issues that are significant as much aggression and violence in sport. The explanation for violent behavior in humans is often the subject of research in the science of sociology. Social changes around the world in the recent centuries had a significant impact on cultural structure. The aggression is a type of behavior that the aggressive person imposes his desires to others using state violence. Some experts of a behavioral science such as Freud and Lorenz believed that aggressive behavior is rooted in the soul of humans. The violence may occurs as result of the anger. Any behavior that is aimed at the introduction of damage to one or more individuals can be called as the aggressive behavior. The study of aggression in sport area is very considerable; in this regard, most of social scientists argued that sport is a reflection of our society in its entirety. Therefore, it can be said that the sport is a small world of a greater world. Unfortunately, the dominance of the athletes' aggressive behavior is increasing since then, it becomes the main issue of the known sports competition. The violence can be occurring in an informed or noninformed manner, since 1970s, the investigation of criminal feminist offenses and women experiences in justice system that is under the dominance of the default situation of gender is considered about the proper role of men and women. Therefore, the violence has different dimensions and appears in various age, gender, and society groups; furthermore, this study considered examining and comparing the aggression between the semi-professional and professional male athletes in Taekwondo in Isfahan, Iran. Eysenck claims that there is a relationship between extrovert, adventurous, and arrogant guy and the deviant behavior that has a quick reaction. He tends to be aggressive, short temperedness, has no control on his emotions. He acts without reflection and thought (America Psychological Association, 2000; Heydari, Asgari, \& Marmazi, 2006). Mental organization is such that reacts for each threatening factor, and usually is one of the most common responses to insecurity, aggression and frustration that attacks and destroys core of the human personality. Lack of good mood due to a mental illness crisis of puberty and behavioral characteristics such as anxiety and excitement, humiliation, pride and aggression will cause the violence. Some factors in these family factors include:

\section{How to deal with the needs of parents and children}

Usually means a child's favorite toy in others hand will cause his anger and he tries to get it even with the violence. Experience shows that if a child is always fulfilled the expectations, he will have more aggressive behaviors than those have not met their expectations. 
The existence of inappropriate patterns

A pattern of human needs, because humans are interested in consisting their life and behavior with their beloved person and those who are their guide and model. The studies have shown that most aggressive young, had violent and hostile parents, it means the aggressive behaviors also impacted on children and they are threatening for the family.

To encourage aggressive behavior

In the case of aggressive behavior by parents will result in positive reinforcement and consolidation of this behavior. When faced with the parents or coaches who teach the child in the name of defending him saying that "be aggressive with whom" "defending himself against whom" and clearly instead of showing reasonable behavior against personal problems will encourage them to be aggressive inappropriately.

\section{To be punished by parents and educators}

Parents and educators that are angry with the aggression and violence of the child, punish him in an aggressive manner, and are effective for his conduct, in such situations, will be the growing and strengthening factor of aggression; in addition, to cause of the anger and possible aggression of the child, the punishing person will become an inconvenient behavioral pattern for the child aggression (Craig, 2006).

Some of these factors are environmental factors that include:

a. Living in very high places and malnutrition; research conducted among Indian Cola tribe in Mial Androperu, which are known as the most aggressive people in the world suggest that the aggression of the tribe is for three reasons: living at altitudes, food shortages, and malnutrition.

b. Chewing coca leaves which contain cocaine and drug and makes consumers feel relaxed temporarily, but the effects of long-term use are harmful for the body's metabolism.

c. Strengthening aggression because of cultural- social losses due to war or other factors; in some cases, it is clear that aggression can be seen in society in such a situation with imagination and acts of aggression more frequently in the minds of society, because the growing demands of the time and place are considered necessary.

d. Social views, viewing the events that are happening in society, such as social conflicts, social limitations, and discrimination injustices caused anger and aggression. 
e. The normality of aggression in the society may cause to believe that the aggression is a "normative" behavior in society, so as compared to communities that do not have such a situation (Raab et al. 1986; Pan, 2005).

\section{Aggression amongst different groups}

Aggression as one of the imperative human behavior that has been considered by various researchers, they explained this factor has related with personality in different groups and locations. In 2002, Sachiko has been examined the relationship between personality traits and aggression. The results of the study showed that there is a positive correlation between neuroticism and aggression. On the other hand, there is negative association between agreeableness, conscientiousness, and openness with aggression among adolescents. In same vein, Nasri and Damavandi (2006) studied the relationship between personality traits and aggression in sports. The consequences revealed that: A) Group of fanatical spectators who have more aggressive behavior, B) the spectators have low self-esteem, feelings and show more aggressive behavior, $\mathrm{C}$ ) there is a positive relationship between the sensation seeking traits, extroversion and hostile behavior. Johnson (2006) conducted a study on the relationship between personality traits and aggression of athletes and concluded that there is a significant negative relationship between vigilance and openness characteristic. Besides, there is a positive relationship between being pleasant and conscientiousness with aggression once the level of consciousness is low. Similarly, Shabanibahar, Erfani, and Hadipour (2006) have been compared and evaluated the relationship between personality and physical traits of aggression between male athletes in different sport fields in Hamadan, Iran. The findings of their investigation showed that there is a significant positive relationship between extraversion and aggression in Taekwondo and Volleyball. In addition, there is a positive significant relationship between lack of stability and stability and the level of aggression in the fields of taekwondo, table tennis and football.

Controversy, Beckmand (2006) conducted a study for the athletes and non-athletes, and concluded that there is no significant relationship between extroversion and hostility. In 2008, Hosseini investigated the relationship between sensation seeking, extroversion, and anger in male offender adolescents in Tehran, Iran. The consequences displayed that there is no significant correlation between extraversion and anger.

According to the previous studies that have been done in the regression area, were mainly achieved among various groups and places. While a survey on aggression among professional and semi-professional male taekwondo players in Isfahan, Iran is still remarkably inadequate. So, the study is conducted to fill in the literature gap. 


\section{Method}

This study concentrated on quantitative approach for the research hypothesizes and determines the comparison of aggression between professional and semi-professional male taekwondo players. Likewise, this study used the cross-sectional design and concentrates on a sample at one point in time. The sample size of the current study was determined based on Cochran's sample size formula. Concerning to this formula has been surveyed three hundred professional and semi-professional male taekwondo players in Isfahan, Iran. For collecting the data, the researchers have been used Buss and Perry (1992) questionnaire that included 29 items and measures aggression types. In the present research has been applied descriptive statistics and t-test for analyzing the data via SPSS.

\section{Results}

Following the hypothesis of this study with the findings of the review are:

H1: there is a difference between the two groups in professional and semiprofessional male athletes in taekwondo department in the province, in terms of aggression.

Table 1

The differences or lack of differences in aggression to separation by means of comparison of averages.

\begin{tabular}{ccccc}
\hline Variable & Group & Number & M & SD \\
\hline Aggression & Professional athlete & 150 & 99.36 & 17.63 \\
& $\begin{array}{c}\text { Non-professional } \\
\text { athlete }\end{array}$ & 150 & 81.72 & 13.39 \\
\hline
\end{tabular}

The above Table shows the average of aggression among groups of professional athletes and professional athletes. In this trait, the group of professional athletes has the average of 17/63 \pm 99/36 and non-professional athletes have an average 13/39 \pm $81 / 72$. So the difference can be seen in this trait in both groups. 
Journal of Educational, Health and Community Psychology

Vol 6, No 2, 2017. E-ISSN 2460-8467

Khozani, Khabiri, Ghadimi, Mehraein, Mehrad

Table 2

Comparison of averages test for independent groups

\begin{tabular}{|c|c|c|c|c|c|c|c|c|c|c|}
\hline \multicolumn{7}{|c|}{ Average comparison test for independent groups } & \multicolumn{2}{|c|}{$\begin{array}{l}\text { Levine test for } \\
\text { equality of } \\
\text { variances }\end{array}$} & \multicolumn{2}{|c|}{ Difference in each group } \\
\hline \multicolumn{2}{|c|}{$\begin{array}{c}\text { Confidence interval of } \\
95 \text { percent }\end{array}$} & \multirow[t]{2}{*}{ SD } & \multirow[t]{2}{*}{ M } & \multirow{2}{*}{$\begin{array}{l}\text { Two- } \\
\text { tailed } \\
\text { Significan } \\
\text { t level. }\end{array}$} & \multirow{2}{*}{$\begin{array}{l}\text { Degrees } \\
\text { of } \\
\text { freedo } \\
\mathrm{m}\end{array}$} & \multirow[t]{2}{*}{$\mathrm{T}$} & \multirow[t]{2}{*}{$\begin{array}{l}\text { Significa } \\
\text { nt level }\end{array}$} & \multirow[t]{2}{*}{$\mathrm{F}$} & & \multirow{4}{*}{ Aggression } \\
\hline $\begin{array}{l}\text { upper } \\
\text { limit }\end{array}$ & lower limit & & & & & & & & & \\
\hline $129 / 11$ & $\begin{array}{c}- \\
36 / 40\end{array}$ & $4 / 424$ & $17 / 82$ & $0 / 022$ & 148 & $2 / 315$ & $0 / 899$ & $\begin{array}{r}1019 \\
0\end{array}$ & $\begin{array}{l}\text { Equality } \\
\text { of } \\
\text { variances }\end{array}$ & \\
\hline $130 / 11$ & $\begin{array}{l}- \\
36 / 40\end{array}$ & $4 / 424$ & $17 / 82$ & $0 / 022$ & $147 / 392$ & 2/315 & & & $\begin{array}{l}\text { Unequal } \\
\text { variances }\end{array}$ & \\
\hline
\end{tabular}

According to the research hypothesis and significance level, two domains of $(0 / 022)$ that is less than $0 / 05(0.05 \mathrm{P})$, and the lower and upper limits obtained with $95 \%$ confidence interval indicates the difference in aggression in separate groups, in other words, the aggression is more in Taekwondo professional group and H1 is confirmed.

$\mathrm{H} 2$ : there is a difference in terms of anger between professional and semiprofessional male athletes between the two groups in the field of Taekwondo in the province.

Table 3

Anger to resolution of differences or lack of Difference

\begin{tabular}{cccccc}
\hline Variable & Group & Number & M & SD \\
\hline Anger & Male & $\begin{array}{c}\text { Professional } \\
\text { athlete } \\
\text { Non-professional } \\
\text { athlete }\end{array}$ & 150 & $24 / 03$ & $2 / 01$ \\
& & 150 & $23 / 07$ & $1 / 81$ \\
\hline
\end{tabular}

The above table shows the average rage among professional and non-professional athletes of taekwondo. The professional group has the average 2/01 $\pm 24 / 03$ and nonprofessional groups have an average of $1 / 81 \pm 23 / 07$. So there is a difference in the characteristics between the two groups. 
Journal of Educational, Health and Community Psychology

Vol 6, No 2, 2017. E-ISSN 2460-8467

Khozani, Khabiri, Ghadimi, Mehraein, Mehrad

Table 4

Comparison of averages test for independent groups

\begin{tabular}{|c|c|c|c|c|c|c|c|c|}
\hline \multicolumn{7}{|c|}{ Average comparison test for independent groups } & $\begin{array}{c}\text { Levine test for } \\
\text { equality of } \\
\text { variances }\end{array}$ & \multirow[t]{3}{*}{$\begin{array}{l}\text { Difference in each } \\
\text { group }\end{array}$} \\
\hline $\begin{array}{l}\text { Confi } \\
\text { interv } \\
95 \text { pe }\end{array}$ & $\begin{array}{l}\text { dence } \\
\text { ral of } \\
\text { rcent }\end{array}$ & SD & \multirow[t]{2}{*}{$\mathrm{M}$} & \multirow[t]{2}{*}{$\begin{array}{l}\text { Two-tailed } \\
\text { Significant } \\
\text { level. }\end{array}$} & \multirow[t]{2}{*}{$\begin{array}{l}\text { Degrees } \\
\text { of } \\
\text { freedom }\end{array}$} & \multirow[t]{2}{*}{$\mathrm{t}$} & \multirow[t]{2}{*}{$\begin{array}{c}\text { Significant } \\
\text { level }\end{array} \quad F$} & \\
\hline $\begin{array}{l}\text { upper } \\
\text { limit }\end{array}$ & $\begin{array}{l}\text { lower } \\
\text { limit }\end{array}$ & & & & & & & \\
\hline $34 / 02$ & 9/47 & $0 / 2591$ & $1 / 143$ & $0 / 569$ & 148 & $0 / 281$ & $0 / 286 \quad 1 / 198$ & $\begin{array}{l}\text { Equality of Anger } \\
\text { variances }\end{array}$ \\
\hline $34 / 02$ & 9/47 & $0 / 2591$ & $1 / 142$ & $0 / 569$ & $141 / 433$ & $0 / 281$ & & $\begin{array}{l}\text { Unequal } \\
\text { variances }\end{array}$ \\
\hline
\end{tabular}

According to the research hypothesis and significance level domains (0/569) that is more than $0 / 05$, and lower and upper limits obtained with $95 \%$ confidence intervals showed no significant difference to the anger of separate groups in other words, there is no significant differences based on the anger in professional athletes with nonprofessional athletes, and the second is rejected.

H3: there are differences in terms of physical aggression between the two groups in professional and semi-professional male athletes in taekwondo department in the province.

Table 5

The differences or lack of differences physical aggression to separation by means of comparison of averages

\begin{tabular}{ccccc}
\hline Variable & Group & Number & M & SD \\
\hline Physical aggression & Professional athlete & 150 & 34.10 & 2.31 \\
& $\begin{array}{c}\text { Non-professional } \\
\text { athlete }\end{array}$ & 150 & 36.79 & 1.97 \\
\hline
\end{tabular}

Table above shows the average physical aggression between male taekwondo professional and amateur. The professional group has the average of 2/31 $\pm 34 / 10$ and $1 / 97 \pm 36 / 79$ is the average of unprofessional. So there is a difference in the characteristics between the two groups. 
Journal of Educational, Health and Community Psychology

Vol 6, No 2, 2017. E-ISSN 2460-8467

Khozani, Khabiri, Ghadimi, Mehraein, Mehrad

Table 6

Comparison of averages test for independent groups

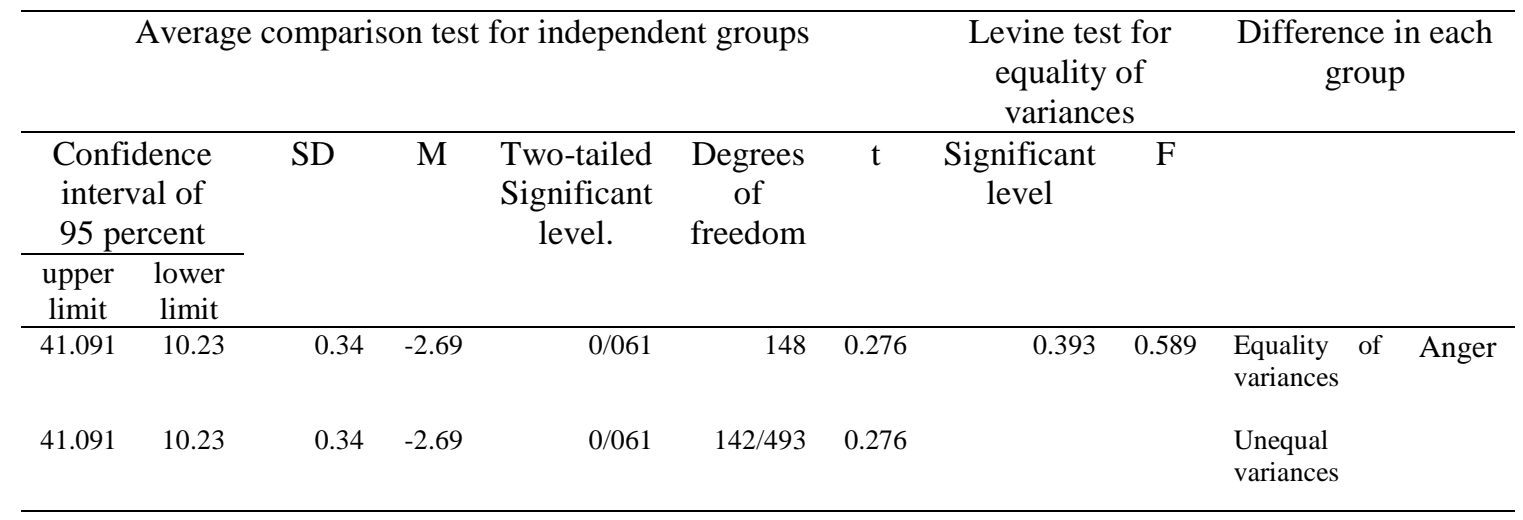

According to the research hypothesis and significance level domains (0/061), more than $0 / 05$, and lower and upper limits obtained with $95 \%$ confidence intervals showed no significant differences physical aggression to separate groups of the study in other words, there is no significant difference between physical aggression in professional and non-professional Taekwondo and third hypothesis is rejected.

H4: there is a differences in terms of verbal aggression between professional and semi-professional male athletes and the two groups in the field of Taekwondo in Isfahan province.

Table 7

Verbal aggression to resolution of differences or lack of Difference

\begin{tabular}{|c|c|c|c|c|}
\hline Variable & Group & Number & $\mathrm{M}$ & SD \\
\hline \multirow[t]{2}{*}{ Verbal aggression } & Professional athlete & 150 & 19.09 & 1.21 \\
\hline & $\begin{array}{c}\text { Non-professional } \\
\text { athlete }\end{array}$ & 150 & 14.49 & 1.79 \\
\hline
\end{tabular}

The Table above shows the average verbal aggression among male athletes, professional and non-professional group. In this trait groups of professional athletes have the average of $1 / 21 \pm 19 / 09$ and non-professional group have average of 1/79 \pm 14/49. So the difference in this trait can be seen in both groups. 
Journal of Educational, Health and Community Psychology

Vol 6, No 2, 2017. E-ISSN 2460-8467

Khozani, Khabiri, Ghadimi, Mehraein, Mehrad

Table 8

Comparison of averages test for independent groups

\begin{tabular}{|c|c|c|c|c|c|c|c|}
\hline \multicolumn{6}{|c|}{ Average comparison test for independent groups } & $\begin{array}{c}\text { Levine test for } \\
\text { equality of } \\
\text { variances }\end{array}$ & \multirow[t]{2}{*}{$\begin{array}{l}\text { Difference in each } \\
\text { group }\end{array}$} \\
\hline $\begin{array}{l}\text { Confidence } \\
\text { interval of } \\
95 \text { percent }\end{array}$ & SD & M & $\begin{array}{c}\text { Two-tailed } \\
\text { Significant } \\
\text { level. }\end{array}$ & $\begin{array}{l}\text { Degrees } \\
\text { of } \\
\text { freedom }\end{array}$ & $\mathrm{t}$ & $\begin{array}{cc}\text { Significant } \\
\text { level }\end{array} \quad F$ & \\
\hline $\begin{array}{ll}\text { upper } & \text { lower } \\
\text { limit } & \text { limit }\end{array}$ & & & & & & & \\
\hline 22.02 & $-0 / 5827$ & 4.59 & 0.029 & 148 & 2.012 & 0.733 & $\begin{array}{l}\text { Equality of Anger } \\
\text { variances }\end{array}$ \\
\hline 22.02 & $-0 / 5827$ & 4.59 & 0.029 & $146 / 681$ & 2.012 & & $\begin{array}{l}\text { Unequal } \\
\text { variances }\end{array}$ \\
\hline
\end{tabular}

According to the research hypothesis and significance level domains (0/29) of less than $0 / 05$, and the top and bottom 95 percent earned significant differences verbal aggression to separate the groups studied, in other words, there is a significant difference between verbal aggression in most of the non-professional athletes, and fourth assumption is confirmed.

H5: there is a difference in terms of hostility between professional and semiprofessional male athletes between the two groups in the field of Taekwondo in Isfahan province.

Table 9

Hostility to resolution of differences or lack of Difference

\begin{tabular}{ccccc}
\hline Variable & Group & Number & M & SD \\
\hline Hostility & Professional athlete & 150 & 29.34 & 2.45 \\
& $\begin{array}{c}\text { Non-professional } \\
\text { athlete }\end{array}$ & 150 & 24.28 & 3.32 \\
\hline
\end{tabular}

The above Table shows taekwondo mean hostility between professional and nonprofessional. The quality of professional male taekwondo group has the average of $2 / 45 \pm 29 / 34$ and 3/32 $\pm 24 / 28$ lay their average. So the difference in this trait can be seen in both groups. 
Journal of Educational, Health and Community Psychology

Vol 6, No 2, 2017. E-ISSN 2460-8467

Khozani, Khabiri, Ghadimi, Mehraein, Mehrad

Table 10

Comparison of averages test for independent groups

\begin{tabular}{|c|c|c|c|c|c|c|c|c|c|}
\hline \multicolumn{7}{|c|}{ Average comparison test for independent groups } & \multicolumn{2}{|c|}{$\begin{array}{c}\text { Levine test for } \\
\text { equality of } \\
\text { variances }\end{array}$} & \multirow[t]{2}{*}{$\begin{array}{l}\text { Difference in each } \\
\text { group }\end{array}$} \\
\hline $\begin{array}{l}\text { Confic } \\
\text { interv } \\
95 \text { pe }\end{array}$ & $\begin{array}{l}\text { lence } \\
\text { al of } \\
\text { rcent }\end{array}$ & SD & $\mathrm{M}$ & $\begin{array}{c}\text { Two-tailed } \\
\text { Significant } \\
\text { level. }\end{array}$ & $\begin{array}{l}\text { Degrees } \\
\text { of } \\
\text { freedom }\end{array}$ & $\mathrm{t}$ & $\begin{array}{c}\text { Significant } \\
\text { level }\end{array}$ & $\mathrm{F}$ & \\
\hline $\begin{array}{l}\text { upper } \\
\text { limit }\end{array}$ & $\begin{array}{l}\text { lower } \\
\text { limit }\end{array}$ & & & & & & & & \\
\hline 38.009 & 9.52 & $-0 / 86997$ & 5.59 & 0.031 & 148 & 2.402 & 0.681 & 0.038 & $\begin{array}{l}\text { Equality of Anger } \\
\text { variances }\end{array}$ \\
\hline 38.009 & 9.52 & $-0 / 86997$ & 5.59 & 0.031 & 147.903 & 2.402 & & & $\begin{array}{l}\text { Unequal } \\
\text { variances }\end{array}$ \\
\hline
\end{tabular}

According to the research hypothesis and significance level domains (0/031) of less than $0 / 05$, and the top and bottom 95 percent earned significant differences hostility index for each group of the study, in other words, there is a significant differences between professional and non-professional male athletes hostility in the groups and fifth assumption is confirmed.

\section{Discussion}

The objective of this research was to compare the aggression of professional and semi-professional male taekwondo players in Isfahan, Iran. The comparison between professional and semi-professional has been displayed the amount of aggression amongst professional athletes was more than semi-professional athletes. In reality, this result shown that years of exercises and competition have considerable role in increasing the athletes' aggression. In other word, the professional athletes based on their years of activities and competition revealed more aggression as compared to semi-professional athletes. As well, verbal aggression and hostility were different between professional; and semi-professional athletes' taekwondo. The professional athletes have shown more hostility as compared to semi-professional athletes. In fact, the amount of hostility that professional athletes illustrated in during of activities and completion was more than semi-professional athletes. Professional athletes likewise illustrated more verbal aggression compared with semi-professionals. This result was so clear during of their exercises. Controversy, terms of anger and physical anger were not different amongst the group of participants. In actual fact, professional and semi-professionals athletes have same average in to theses reactions. 
Based on previous studies such as Nasri and Damavandi (2006), Johnson (2006), and Shabanibahar et al. (2006) the overall aggression has direct association with individual personality. Beside, in the current study aggression has close relation with the amount of professionality and years of exercise. These findings displayed that years of activity in sport and competition have direct association with behavior and reaction of athletes.

\section{Conclusion}

Aggression assumed as basic human behavior that can cover most of relation and activities of individuals. In this regard concerning to this factor is so imperative. Additionally, most of psychologists and sociologists focused on it, comprehensively. This human behavior factor that determined as negative factor should be consider and control by individuals, because lack of attention to it lead to many abnormality and difficulties in athletes' personal and social life. Based on these concerns, athletes and the sport community or sport organization have noticeable responsibility toward sport and any things that related to it; Furthermore, they should be aware toward any things that have negative impression on sport. Most of athletes are not inform about the importance effect of environment, culture, society etc. that have great impact on human behavior and should be control carefully.

Then, it is necessary the sport organizations determine appropriate structures and policies for controlling athletes feeling and behavior. Likewise, the athletes have to know themselves and endeavor to cope with on undesirable factors that make them aggressive.

\section{References}

America Psychiatric Association. (2000). Diagnostic and Statistical Manual disorders mental revised text translation of MR Nikkhooi, Hamayak Avadis Yancey (2002). (4 ${ }^{\text {th }}$ ed.). Published by speech: sport sociology in Tehran.

Beckmand. W. (2006). Personality and mood of former elite athletes 'descriptive study. Sport Med, 22, 215-221.

Craig, L. A., Browne, K. D., Beech, A., \& Stringer, I. (2006). Differences in personality and risk characteristics in sex, violent and general offenders. Criminal Behavior and Mental Health, 16, 183-194.

Heydari, A. R, Asgari, P., \& Marmazi, A. (2006). Compared the personality traits of gifted students and ordinary secondary schools in Ahvaz. Journal of Psychology, Islamic Azad University of Ahvaz, 144-96. 
Hosseini, S. M. (2008). The relationship between sensation seeking, extroversion and anger in adolescents' offenders and non-sports sociology in Tehran province (Master thesis), Ferdowsi University of Mashhad, Faculty of Educational Sciences.

Jensen, L. A. (2006). Do big five personality traits associated with self-control influence the regulation of anger and aggression? Research in Personality, 34 46

Nasri, S., \& Damavandi, E. (2006). The relation between personality features and aggression in football spectators. Journal of Psychology and Training Sciences, $1,54-9$.

Pan, Q. M. (2005). Adolescent aggression: Dimensions, structure and related studies. Master Dissertation of South China Normal University.

Raab, A., Dantzer, R., Michaud, B, et al. (1986). Behavioral, physiological and immunological consequences of social status and aggression in chronically coexisting resident-intruder dyads of male rats. Physiol Behav, 36, 223-228.

Sachiko, S. (2002). An analysis of the relationship between aggressiveness and personality traits of children. Japanese Psychological Association. Tokyo, Japan.

Shabanibahar, G., Erfani, N., \& Hadipour, M. (2006). Compare and evaluate the relationship between personality traits and aggression among male athletes in selected sports disciplines in the Hamedan. J Sports Sci, 14, 99-112. 